\title{
Audit Committee Characteristics and Earnings Management: Evidence from India
}

\author{
Mamta Mishra (Corresponding author) \\ Research Scholar, School of Management Studies \\ Ansal University, Gurgaon, India \\ Email: mamta111@yahoo.com \\ Dr. Amarjeet Kaur Malhotra \\ Professor, School of Management Studies \\ Ansal University, Gurgaon, India
}

Received: September 11, 2016 Accepted: October 23, 2016 Published: November 27, 2016

doi:10.5296/ijafr.v6i2.10008 URL: http://dx.doi.org/10.5296/ijafr.v6i2.10008

\begin{abstract}
Earnings management is perceived to be a pervasive phenomenon, spread across companies and industries. It distorts earnings quality and portrays an incorrect picture of a firm's financial performance. Accounting frauds in companies originate from a culture of widespread earnings management. Audit committees are a popular corporate governance tool to improve the credibility of financial statements. The study, evidently the first of its kind in India, seeks to examine the effectiveness of audit committees in constraining earnings management in Indian companies. Secondary data is collected for a sample of 130 companies listed on the BSE and studied for a three-year period 2013-2015. Univariate correlations, multivariate linear regression, and logistic regression models are used to conduct empirical analysis. Evidence suggests significant impact of audit committee size, multiple directorships of audit committee members and frequency of audit committee meetings on earnings quality. Other audit committee characteristics are not found to have a significant impact on the level of earnings management. Findings of the study throw up useful insights for regulators and company boards to evaluate the efficacy of board audit committees and implement additional governance measures to help preserve the integrity of financial statements.
\end{abstract}

Keywords: Audit committees, Earnings management, India, Modified Jones Model, Corporate governance 


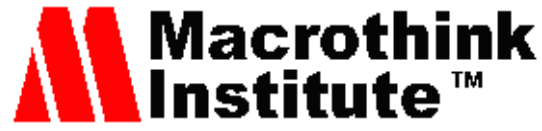

\section{Introduction}

The pressure on companies to meet earnings estimates and analyst expectations has been a compelling force for managers worldwide to resort to earnings management. Share prices of companies are highly susceptible to earnings, and any significant deviation from the expected trend gets penalized through fall in stock prices and valuation dips. Managers are further incentivized to indulge in earnings manipulation due to their compensation being tied to the firms' performance. Earnings management occurs when company managers take advantage of the flexibility provided by accounting rules and standards to match the reported earnings of a company with a preferred or desired level. Several studies conducted in India and across the world confirm the prevalence of earnings management as a pervasive phenomenon.

Earnings management distorts the quality and credibility of financial reporting and can in the process, hamper effective decision making by investors and other stakeholders of a company. Financial information asymmetry hinders the efficient functioning of capital markets and poses a roadblock for regulators who seek to enhance the transparency and stability of financial markets. Ajit et al. (2013) mention that for sustained flow of funds into Indian capital markets, investors need to be protected from accounting frauds, financial misconduct and deceptive earnings management practices. There are arguments that earnings management practices were primarily responsible for the accounting frauds that materialized at Enron, Xerox and WorldCom and the more recent Satyam scam in India (Goncharov 2005; Rajpal 2012).

Adequate governance norms can go a long way in ensuring fair accounting practices and transparency in reporting systems. Corporate governance is a widely acclaimed tool for enhancing investor confidence and promoting wider participation in capital markets. Researchers have put forth numerous definitions of corporate governance. However, the essence of the various definitions has revolved upon maximizing shareholder value and ensuring fair play to the other stakeholders of a company. Shleifer \& Vishny (1997), in their acclaimed survey of literature, state that corporate governance is concerned with the ways in which capital providers to firms ensure return on their investment. Singh, Kumar, \& Uzma (2010) have identified four limbs, which constitute most corporate governance models presence of independent directors on board, audit committees with appropriate powers to oversee the financial reporting, accounting and auditing process, transparency and disclosures and certification of accounts and related statements by CEOs and CFOs.

The alarming rise in corporate failures and accounting scandals has caused a paradigm shift in the way companies are getting governed. The Sarbanes-Oxley (2002) Act passed by the US Senate was seen as America's answer to the huge public outcry that followed the massive debacles of Enron and WorldCom. Corporate scams and financial reporting malpractices are not restricted to any particular country. India too has had its fair share of corporate frauds. The UTI scam of 1990s, Ketan Parekh securities scam, the collapse of Global Trust Bank and the recent Satyam fiasco are glaring examples of auditing and governance failure. Aptly described as "India's Enron," Satyam has become an important case study in many business schools, highlighting the loopholes in systems of internal control and corporate governance. 


\section{$\Lambda$ Macrothink}

International Journal of Accounting and Financial Reporting ISSN 2162-3082

Both Satyam and Enron have been primarily responsible for overhauling the systems of corporate governance in India and the U.S. respectively.

Corporate governance norms in most developed and developing countries require the constitution of a board audit committee to oversee the financial reporting and auditing process. Professional accounting and auditing bodies endorse the constitution of an audit committee as it lends greater credibility to financial statements and enhances public confidence in the integrity of the external auditor. Puri et al. (2010) mention that audit committees act as a communication channel between the board of directors and external auditors.

The present study attempts to look into the effectiveness of audit committees in constraining earnings management in listed Indian companies. Audit committees are responsible for reviewing the financial statements of the company and to ensure that they portray a fair picture of the firm's actual performance. The paper seeks to evaluate the role of audit committees in being able to prevent or reduce earnings manipulation by managers. The findings of the research are likely to be useful to regulators, lawmakers and company boards in evaluating efficacy of audit committees in ensuring earnings quality.

\section{Literature Review and Hypothesis Development}

The impact of audit committee characteristics on earnings quality has been researched by some academicians, but their studies have been mostly restricted to developed economies. Evidence from emerging markets is scant, with most research in developing countries like India, having concentrated on the impact of corporate governance reforms on firm performance and market value (Claessens \& Fan, 2002; Mohanty, 2003; Black et al., 2006). The few studies that exist for earnings management in emerging economies have largely explored the association between earnings management and ownership and control structures in firms (Sarkar et al., 2008).

The hypothesis for this study is developed based on the review of the extant literature in this area.

\subsection{Audit Committee Size}

Size of audit committee refers to the number of members constituting the audit committee. In India, the Companies Act (2013) requires audit committees to consist of a minimum of three members. A survey of the previous literature finds inconsistent conclusions on the impact of audit committee size on improving earnings quality. Hamdan et al. (2013) attempted to measure earnings quality in Jordan companies through future continuity of cash flows as well as presence of discretionary accruals in returns. They found a negative relationship between audit committee size and earnings quality, as reflected through continuity of future returns. They, however, did not find any significant relationship between size of audit committee and quantum of discretionary accruals present in returns. Qaraqish (2009) also found no relationship between audit committee size and improvement in earnings quality. A similar conclusion was reached by Davidson et al. (2005). In their study of 434 listed Australian firms, they did not find any association between the level of discretionary accruals and size of 
audit committees.

Lin \& Yang (2006) suggest that larger audit committees do a better job at monitoring the financial reporting process, and consequently improve earnings quality. Size of audit committees helps to shrink the magnitude of cheating and forgery in financial statements (Huang \& Liu, 2005). A positive relationship between audit committee size and quality of financial reports was also found by Hamdan \& Mushtaha (2011) and Felo et. al (2003). Large boards can draw from the diverse skills and expertise of their members to enhance monitoring and reduce the incidence of earnings management.

Al-Farah (2011) recorded contradictory findings for Jordanian firms. A large committee size can be unwieldy and result in cost wastage and muddling of work, thereby leading to a decrease in the efficacy of audit committee function. Also, smaller committees might be more effective as they are able to make timely strategic decisions (Goodstein et al. 1994).

In the Indian context, there seems to be a conspicuous absence of studies that have attempted to explain the influence of audit committee size on earnings management. Based on the confounding effect of this variable on earnings management and an apparent absence of studies from an Indian perspective, the first hypothesis is drawn up in the null form:

\section{H1: Size of the audit committee has no significant impact on earnings management}

\subsection{Audit Committee Independence}

An independent director is a person who does not hold any material pecuniary relationship with the company or persons related to the company, which might affect his /her independence. An independent audit committee is likely to be free from management pressure, and may be more effective in monitoring the financial reporting process. However, a study of the existing literature reveals inconsistencies regarding audit committee independence and its effectiveness in being able to reduce earnings management.

Bedard et al. (2004) in their study of 300 U.S. firms, find that a majority of independent directors on the audit committee is not sufficient to curtail earnings management. Their results suggest that only a $100 \%$ independent audit committee can result in efficient monitoring and reduce the level of aggressive earnings management in companies. Their findings support the requirements of the SOX Act that mandates for a $100 \%$ independent audit committee. Similar findings are also documented by Abbott et al. (2002), who state that a completely independent audit committee is significantly associated with a lower incidence of financial misstatement. The results of Bedard et al. can be contrasted with that of Klein (2002), who mentions that once majority of directors on the audit committee are independent, the independence of the remaining directors becomes immaterial. As per Klein, there appears to be a significant association between abnormal accruals and the presence of a majority of independent directors on the audit committee. She however, does not find any meaningful relation between earnings manipulation and an audit committee comprised solely of independent directors. Lin \& Yang (2006) studied 106 publicly held firms in the U.S. that restated their reported earnings for the fiscal year 2000. They find no significant influence of audit committee independence on occurrence of earnings restatement and quality of financial 


\section{Ml Macrothink}

International Journal of Accounting and Financial Reporting

ISSN 2162-3082

2016, Vol. 6, No. 2

reports. Van der Zahn \& Tower (2004) tried to investigate the link between audit committees and earnings management using a sample of 485 firm-years from Singapore listed companies during 2000-2001. Their findings signify that audit committees with a higher proportion of independent members are more effective at constraining earnings management.

In India, there seems to be an apparent lack of research exploring the impact of audit committee independence on earnings management. Indian corporate laws mandate for majority of audit committee members to be independent directors. Regulatory emphasis and supporting international studies largely point towards a negative association between audit committee independence and earnings management.

H2: Independence of audit committee has a negative significant impact on earnings management

\subsection{Audit committee multiple directorships}

In India, the Companies Act, 2013 has raised the limit for the maximum number of directorships in public companies than can be held by an individual from 12 to 15 . Additionally, the law states that a director cannot be a member of more than ten committees or chairman of more than five committees, across all the companies in which he is a director.

Studies exploring the impact of multiple directorships on earnings management yield mixed results. A section of researchers conclude that multiple directorships are an indicator of director reputation and expertise. Directors on multiple boards are exposed to different management policies, styles and practices, which adds to their monitoring competencies. An audit committee member holding directorships across companies brings in varied knowledge and experience, which aids in effective monitoring across diverse situations. (Dooley, 1969; Davidson et al. 1984; Ferris et al., 2003; Sharma and Iseline, 2006). However, too many directorships also imply paucity of time and may constrain an audit committee member from discharging his duty effectively (Beasley, 1996). This can increase the likelihood of financial statement fraud. A similar argument is also put forward by Jiraporn et al. (2008). Multiple directorships reduce effective monitoring and can cause a reduction in shareholder's wealth.

In India too, studies exploring the impact of multiple directorships on earnings management show contrasting results. Sarkar et. al (2008) examined the impact of busyness of board of directors on earnings management, for a sample of 500 large Indian firms. They find that boards with large number of multiple directors exhibit higher earnings management. On the other hand, Rajpal (2012) in his study of 200 listed large firms in India concludes that when independent directors hold multiple directorships in other companies, they are able to use their diverse experience to constrain earnings management practices.

Another important consideration that merits discussion is the threshold defining 'multiple directorships'. In the U.S., an audit committee member can sit on the board of three other public companies. Beyond three other companies, the New York Stock Exchange (2003) requires the related board of directors to consider whether the additional directorships would impair the monitoring effectiveness of the concerned audit committee member. In India, laws permit an audit committee member to be a member in a maximum of 10 other committees. 


\section{MInstitute Macrothink $_{\text {Int }}$}

International Journal of Accounting and Financial Reporting ISSN 2162-3082 2016, Vol. 6, No. 2

However, existing studies in India have followed a conservative approach to define busyness. Sarkar et al. (2008) adopt the rule of thumb used to define busyness, as in several U.S. studies. A similar approach is also used by Rajpal (2012). Both these studies identify director busyness as 'membership in more than three other boards'. To ensure consistency with the existing literature, this study considers the threshold of 'three other board memberships' as the criteria for multiple directorships. Given the competing views on this subject, a null hypothesis is proposed between multiple directorships and earnings management.

H3: There is no significant impact of multiple directorships of audit committee members on earnings management.

\subsection{Audit committee expertise}

Audit committees are responsible for monitoring the financial reporting process as well as ensuring the credibility of financial statements. It is but imperative that audit committee members possess a certain degree of financial expertise. Corporate governance regulations across the world recognize the importance of financial expertise for audit committee members. In the U.S., the SOX (2002) Act mandates that at least one member of the audit committee must be a financial expert. Similar requirements are also spelt out in the Smith report (2003) in the U.K. In India, the Companies act (2013) requires the majority of audit committee members, including the chairperson to possess the ability to read and understand financial statements. However, clause 49 of SEBI's listing agreement requires all audit committee members to be financially literate and at least one member to possess accounting or related financial management expertise (Board Committees, 2014)

Kuang (2007) highlights BRC (1999) definition to bring out the difference between financial expertise and financial literacy. Financial expertise implies relevant employment experience or professional qualification in accounting/finance, whereas financial literacy refers to the ability to read and understand basic financial statements. The study draws upon Kuang's (2007) demarcation of financial expertise from financial literacy. In India, the emphasis is upon majority of audit committee members to possess financial literacy. However, given the specialized role of audit committees, the study attempts to examine the impact of financial expertise of audit committee members on earnings management.

A review of the extant literature reveals a positive correlation between financial experience of audit committee members and quality of financial reports (Bryan et al., 2004; Qin, 2007; Hamdan \& Mushtaha, 2011; Emmanuel et al., 2014). Conversely, a negative association is documented between audit committee expertise and earnings management (Bedard et al. 2004; Yang \& Krishnan, 2005; Kuang 2007). Though much of the existing research purports an association between financial expertise of audit committee members and earnings quality, few studies in the U.S. claim otherwise. The findings of Abbott et al. (2004) support those of Xie et al. (2003) that earnings quality is independent of financial experience of audit committee members.

Audit committees with financial experience are also more effective when it comes to dealing with external auditors. DeZoort (1998) states that knowledgeable audit committees are better 
equipped to resolve auditor-management conflicts. Likewise, when the external auditors believe that the audit committee does not possess the knowledge necessary to discern financial intricacies, they tend to discount the supervisory role of the audit committee (Knapp, 1987).

The existing research suggests that an audit committee with financial experts has a significant influence on earnings quality and financial reports. Based on the above indicators and existing regulations worldwide, the study predicts a negative relationship between audit committee expertise and earnings management.

H4: There is a significant negative impact of audit committee expertise on earnings management.

\subsection{Audit committee meetings}

Previous studies in India and abroad measure the diligence of audit committees and the board by their annual meeting frequency. As per Menon \& Williams (1994), the number of audit committee meetings is a proxy for diligence, as an inactive committee is less likely to perform its monitoring duties effectively.

In India, the laws require audit committees to meet at least four times in a year, with a gap of not more than four months between two meetings. This is in the line with the recommendations of the BRC (1999) in the U.S., which recommends four audit committee meetings per year, corresponding with reviews of the quarterly financial statements. Abbott et al. (2004) mention that meeting frequency of audit committees may be perceived as a measure of their diligence in monitoring the quarterly statements. They conclude that a higher level of committee activity (measured by a minimum of four audit committee meetings) is significantly associated with a lower incidence of financial misstatement.

Past studies however, fail to provide sufficient evidence of the impact of audit committee meetings on earnings management. Xie et al. (2003) and Lin et al. (2006) show a negative association between the number of audit committee meetings and earnings management. Audit committees that meet more frequently have greater opportunities to discuss financial reporting issues and may be more effective in preventing financial statement fraud (Abbott et al., 2004). These findings are supported by Lin \& Hwang (2010), who report a significant positive effect of an active audit committee on the quality of financial reports. Committees that meet more frequently are likely to be more proactive and demanding in ensuring earnings quality.

Some academicians challenge the perception of higher number of audit committee meetings as a proactive measure. They report that audit committee meetings are more of a reaction to a dilemma. Ghosh et al. (2010) suggest a positive relation between earnings management and the frequency of audit committee meetings, corroborating the findings of Jensen (1993) and Vafeas (1999) that audit committees meetings are largely a reactionary measure to address an escalating problem. An increase in the frequency of audit committee meetings signifies the presence of problems. 


\section{Mll Macrothink}

International Journal of Accounting and Financial Reporting

ISSN 2162-3082

2016, Vol. 6, No. 2

Bedard et al. (2004) in their study of U.S. firms, find no significant association between frequency of audit committee meetings and aggressive earnings management. Their results are supported by Yang \& Krishnan (2005), who also find no impact of audit committee meetings on quarterly earnings management. From an Indian perspective, Sarkar et al. (2008) show that a diligent board that meets frequently is associated with a lower level of earnings management. However, a later study by Rajpal (2012) finds no such association.

Due to the ambiguous findings of the impact of audit committee meetings on earnings management, the study proposes a hypothesis in the null form.

H5: There is no significant impact of audit committee meetings on earnings management.

\section{Research Design}

\subsection{Sample Selection and Data Collection}

This study is a cross-sectional analysis of companies listed on the Bombay Stock Exchange (BSE). It seeks to examine the impact of audit committees in constraining earnings management in firms' of varying market capitalization. Prior studies hint towards more aggressive earnings management practices in the smaller companies than the larger ones (Ajit et al. 2013). This study focuses on the earnings quality in the large cap, mid-cap and smallcap sectors.

Companies listed on the BSE constitute the target population for the study. The S\&P BSE 100, BSE mid-cap and BSE small-cap indices constitute the sampling frames, and samples for the study are drawn from these indices. Finance companies and public sector undertakings are excluded from the sample, as they are subject to different regulatory and procedural requirements that render their financial data incomparable with others. Two-stage cluster sampling technique is used to draw the sample for the study. The population is divided into clusters based on the industry classification of firms. Simple random sampling is applied to draw a random sample of 15 clusters. Sampling frame is then used to draw elements (firms) from the clusters.

In line with the sample size used in similar studies (Bedard et al., 2004; Van der Zahn \& Tower, 2004; Kuang, 2007) studies, an initial sample of 200 companies is drawn from the final sampling universe of 727 companies (Table 1). Firms with insufficient information to construct all proxy measures are excluded from the sample. Consistent with prior research and to ensure representative co-efficient estimates for the modified Jones (1995) model, a minimum of ten firms need to exist for each industry in each year (Klein 2002, Abdul Rahman \& Haneem Mohamed Ali 2006, Sarkar et al. 2008). Accordingly, firms belonging to industries with less than ten observations are excluded from the sample. The final sample consists of 130 companies, studied for a three-year period 2013-2015. Quality and presentation of financial data tends to vary over time. A three-year time period is chosen to ensure the data remains comparable for conducting empirical analysis. 


\section{Macrothink \\ International Journal of Accounting and Financial Reporting

Table 1: Sample Formation

\begin{tabular}{|l|l|}
\hline & Number \\
\hline $\begin{array}{l}\text { Companies constituting the BSE } \\
\text { sensex, BSE Midcap and BSE } \\
\text { Smallcap indices as on 10 } \\
\text { December 2015 }\end{array}$ & 849 \\
\hline $\begin{array}{l}\text { Less: Financial companies and } \\
\text { Public sector undertakings included } \\
\text { in the above indices }\end{array}$ & 122 \\
\hline $\begin{array}{l}\text { Final Sample Universe } \\
\text { Initial sample (drawn from the } \\
\text { universe) }\end{array}$ & 200 \\
\hline $\begin{array}{l}\text { Less: Firms with insufficient } \\
\text { information to construct all proxy } \\
\text { measures }\end{array}$ & 56 \\
\hline $\begin{array}{l}\text { Less: Firms from industries with } \\
\text { less than ten observations }\end{array}$ & 14 \\
\hline $\begin{array}{l}\text { Final Sample used in the study of firm year observations } \\
\text { (130) from 2013-2015) }\end{array}$ & 130 \\
\hline
\end{tabular}

The data used in the study is secondary in nature, and is sourced from Prowess database maintained by the Center for Monitoring the Indian Economy (CMIE), corporate governance charters, and annual reports of companies. Data for the sample companies is collected for a three-year period ranging from 2013-2015.

\subsection{Variables used in the study}

Existing literature is referred while selecting the various independent and control variables for the study. Lack of information and inconsistent reporting formats across Indian companies (especially for small-cap firms) preclude the inclusion of certain variables that form part of studies conducted in developed markets. Table 2 provides a description of all variables used in the study. 
Table 2: Definition of variables

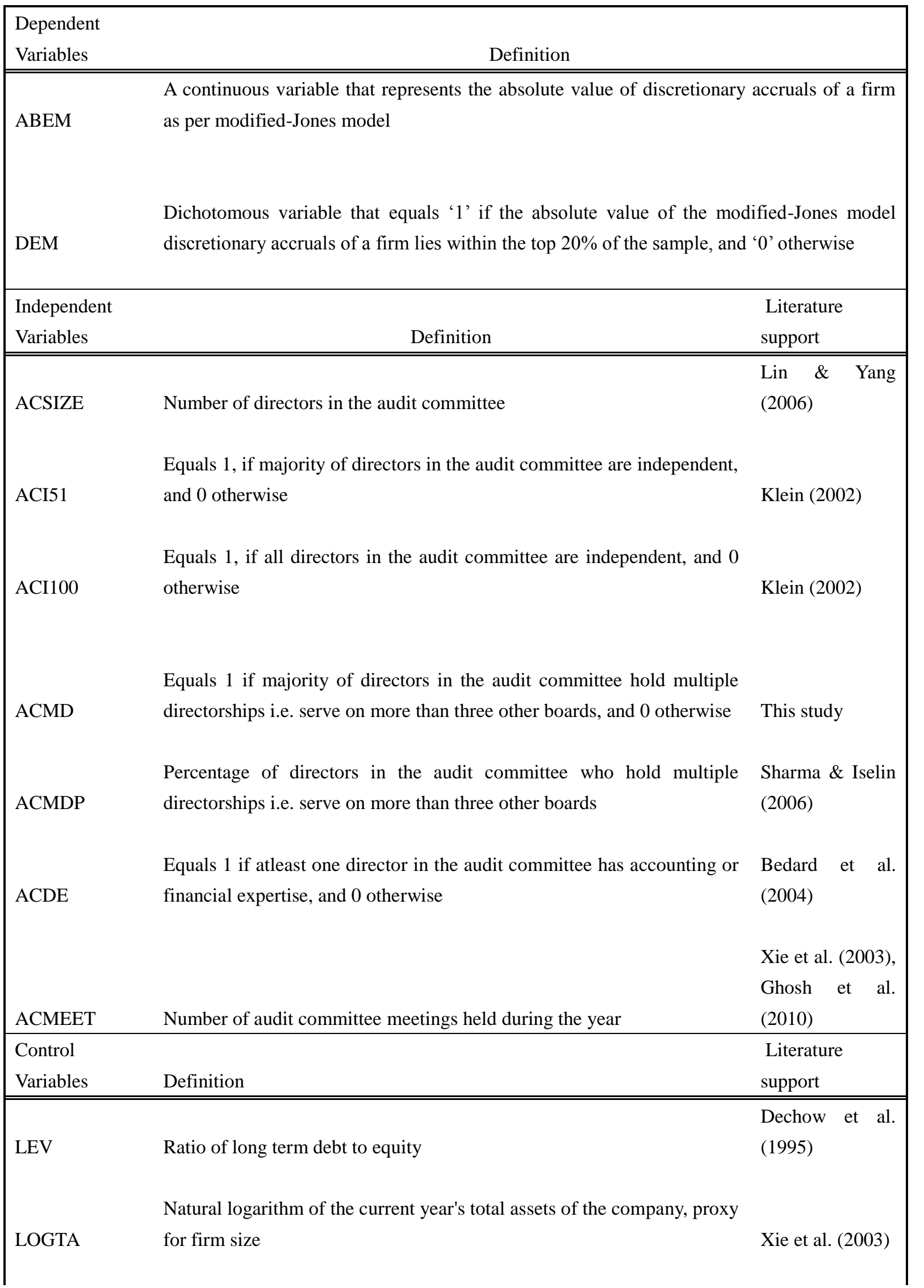




\section{$\triangle$ Macrothink}

International Journal of Accounting and Financial Reporting

ISSN 2162-3082

2016, Vol. 6, No. 2

\begin{tabular}{|lll|}
\hline LOSS & $\begin{array}{l}\text { Equals } 1 \text { if income before extraordinary items is negative for two } \\
\text { consecutive years, and } 0 \text { otherwise }\end{array}$ & Beasley (1996) \\
ABCHPAT & $\begin{array}{l}\text { Absolute value of the change in net income of the firm between current } \\
\text { and previous year, scaled by total assets of the previous year }\end{array}$ & Klein (2002) \\
PB & Ratio of price to book value of share; represents the investment & Klein (2002) \\
& opportunity in the firm & Becker et al. \\
BIG4 & Equals 1 if the firm is audited by a BIG 4 auditor (PwC, KPMG, & (1998)
\end{tabular}

\subsection{Control variables}

Prior studies measuring earnings management suggest that earnings management may be impacted by factors other than audit committee characteristics (Bartov et al., 2000). To control for the effect of these confounding factors as well as improve the robustness of the tests, the study includes certain control variables. These control variables pertain to external monitoring mechanisms and firm performance, which might have some association with earnings management and/or audit committee variables.

The six control variables included in the study are defined in Table 2. A firm's propensity to manage its earnings is higher when it faces a financial crisis. Leverage $(L E V)$ is defined as the ratio of a firm's debt to its net worth. A firm that is close to breaching its debt covenants can be compelled to indulge in earnings manipulation, as a higher leverage ratio can up the risks of bankruptcy and associated litigation. Consistent with prior research, the study uses leverage to control the impact of high debt on earning management (Dechow et al. 1995; Beasley \& Salterio, 2001; Klein, 2002). The size of a firm can also impact its inclination towards earnings management. Small firms are subject to lesser public scrutiny than the big firms and have a greater tendency to manager earnings (Xie et al. 2003). Bartov et al. (2000) and Klein (2002) find that the size of a firm is negatively associated with earnings management, while it bears a positive association with audit committee independence. The study uses log of total assets (LOGTA) to control for the impact of a firm's size. The third control variable included in the study is negative income (LOSS). Beasley (1996) suggests that loss is associated with financial misreporting, whereas Klein (2002) documents a relation between negative income and audit committee independence. The variable LOSS takes a value of ' 1 ' if a firm's income before extraordinary items is negative for two consecutive years, and ' 0 ' otherwise. Klein (2002) reports that the absolute change in earnings is positively associated with earnings management. The study includes the absolute change in earnings ( $A B C H P A T)$ as a control variable and defines it as the absolute change in net income between the current and prior year, scaled by the total assets of the previous year. Price to book ratio $(P B)$, a proxy for investment opportunity, is measured by the market price of a stock divided by the book value of a firm's equity share. Klein (2002) finds this variable significantly affects the independence of the audit committee. Lastly, the study includes an 


\section{NI Macrothink}

International Journal of Accounting and Financial Reporting ISSN 2162-3082 2016, Vol. 6, No. 2

external monitoring mechanism to improve the power of the tests. Firms employing Big4 auditors are less motivated to indulge in earning management. This is because Big4 audit firms display better control over the financial reporting process and are more likely to detect and question management on unscrupulous accounting practices (Becker et al., 1998; Krishnan, 2003). BIG4 is a dummy variable that takes the value of ' 1 ' ' if the firm has a Big4 auditor and ' 0 ' otherwise.

\subsection{Measuring Earnings Management}

One of the greatest problems surrounding earnings management is the difficulty involved in detecting manipulation of financial information from publicly available financial statements. Earnings management is neither visible nor transparent. Over the years, a number of models have been developed to estimate earnings management. Most models focus on the use of discretionary or abnormal accruals as a proxy for earnings management (Kothari et al., 2005). Of all the available models, the modified Jones Model (1995) is the most widely used empirical model and provides the most powerful test of earnings management when compared to the Healy Model, the DeAngelo Model, the Jones model and the Industry Model (Dechow et al. 1995). This conclusion is also supported by Bartov et al. (2000). The present study uses the modified Jones Model (1995), as was adopted by Ajit et al. (2013) for their empirical investigation of earnings management in Indian companies.

\subsubsection{Modified Jones Model}

The modified Jones Model (1995) is used to measure discretionary accruals (DA) that is considered as the proxy for earnings management.

Modified Jones Model uses a staged approach to arrive at discretionary accruals. In the first stage, total accruals (TAC) are calculated using either the cash flow approach or the balance sheet approach. Total accruals represent the gap between the reported operating income and operating cash flows of a company. Based on previous research (Hribar \& Collins 2002; Kuang 2007), the study employs the cash flow approach to determine total accruals.

TAC $=$ Operating Income - Operating Cash Flow

TAC is then decomposed into non-discretionary accruals (NDA) and discretionary accruals (DA), using the cross-sectional modified Jones model (1995). To adjust for differences in firm size, all variables in equation 2 are scaled by the total assets at the end of year $t-1$. This also reduces the problem of heteroskedasticity in the regression residuals (Kothari et al. 2005, Teoh et al. 1998).

$\frac{T A C_{i j, t}}{T A_{i j, t}, 1}=\alpha_{i, t}\left\lfloor\frac{1}{T A_{i j, t} t-1}\right\rfloor+\beta_{i, t}\left[\frac{\Delta R E V_{i j, t}-\Delta R E C_{i j, t}}{T A_{i j, t} t-1}\right]+\gamma_{i, t}\left[\frac{\mathrm{pPE}_{i j, t}}{T A_{i j, t} s}\right]+\varepsilon_{i j, t}$

where, 


\section{Macrothink

$T A C_{i j_{i} t}=$ Total accruals for firm $i$ in industry $j$ in year $t$

$T A_{i j, t-1}=$ Total assets for firm $i$ in industry $j$ at the end of year $t-1$

$\triangle \mathrm{REV}_{\mathrm{ij}, \mathrm{t}}$

$=$ Change in sales for firm $i$ in industry $j$ between years $t-1$ and $t$

$\triangle \mathrm{REC}_{\mathrm{ij}, \mathrm{t}}$

$=$ Change in receivables for firm $i$ in industry $j$ between years $t-1$ and $t$

$\mathrm{PPE}_{\mathrm{ij}, \mathrm{t}}$ $=$ Gross property, plant and equipment for firm $i$ in industry $j$ in year $t$

$\alpha_{i}, \beta_{i,}, \gamma_{i}=$ Industry specific estimated coefficients for year $\mathrm{t}$

$\varepsilon_{i} \quad=$ Error term

The coefficients for equation (2) $\alpha_{i}, \beta_{i}, \gamma_{i}$ are estimated for each year and each industry using cross-sectional data. The estimated coefficient values $\left({ }^{\hat{a}_{i}, \hat{\beta}_{i_{i}}} \hat{\gamma}_{i}\right)$ for each industry in each year are fitted in equation (2) to arrive at non-discretionary accruals (NDA).

Discretionary accruals (DA) are then calculated using equation (3), expressed as:

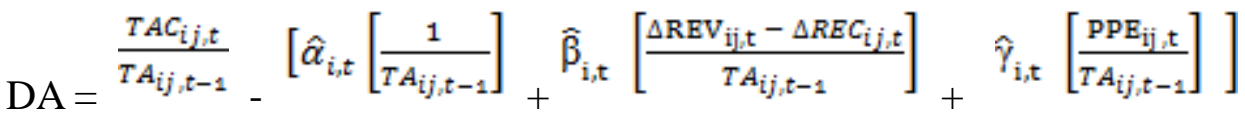

Positive DAs indicate income-increasing manipulations, while negative DAs are for incomedecreasing manipulations. Consistent with existing literature in this field, discretionary accruals as a percentage of total assets are considered as the proxy for the extent of earnings management prevalent in firms. The study uses two measures of discretionary accruals as the dependent variable in the regression models - ABEM and DEM. The variables are explained in Table 2. 


\section{Macrothink \\ International Journal of Accounting and Financial Reporting \\ ISSN 2162-3082 \\ 2016, Vol. 6, No. 2}

\section{Data Analysis \& Empirical Results}

The study makes use of regression models for empirical investigations. The following form of regression is used to examine the association between earnings management and audit committee characteristics.

Earnings management $=\alpha+\mathrm{f}$ (audit committee variables, control variables)

\subsection{Model Specification}

The study uses two types of pooled regression models to measure the impact of audit committee variables on earnings management. The first model uses the ordinary least squares (OLS) method to predict the linear relationship between audit committee variables and the absolute value of discretionary accruals obtained from the modified Jones (1995) model. The second model is a binary logit model, which measures the impact of audit committee variables on the probability of having high discretionary accruals.

\subsection{First model: Linear Regression}

In the first model, the dependent variable 'earnings management' is represented by the continuous variable $A B E M$. The linear regression model is expressed as follows:

$$
\begin{aligned}
& \operatorname{ABEM}_{\mathrm{i}, \mathrm{t}}=\beta_{0}+\beta_{1} \operatorname{ACSIZE}_{\mathrm{i}, \mathrm{t}+} \beta_{2} \mathrm{ACI}_{1, \mathrm{i}, \mathrm{t}+} \beta_{3} \mathrm{ACI}_{100} \mathrm{i}_{\mathrm{i}, \mathrm{t}+} \quad \beta_{4} \mathrm{ACMD}_{\mathrm{i}, \mathrm{t}+} \\
& \beta_{5} \text { ACMDP }_{i, t+} \beta_{6} \text { ACDE }_{i, t+} \beta_{7} \text { ACMEET }_{i, t++} \beta_{8} \operatorname{LEV}_{i, t+} \beta_{9} \operatorname{LOGTA}_{i, t+} \beta_{10} \operatorname{LOSS}_{i, t, t-1+}
\end{aligned}
$$$$
\beta_{11} \text { ABCHPAT }_{i, t, t-1+} \beta_{12} \text { PB }_{i, t+} \beta_{13} \text { BIG4 }_{i, t}+\varepsilon_{i, t}
$$

where, ${ }^{A B E M} M_{i, t}$ the dependent variable is a continuous variable and represents the absolute value of discretionary accruals for the firm $i$ in year $t$.

The remaining variables are explained in Table 2 and represent the observations for firm $\mathrm{i}$ in year $\mathrm{t}$.

\subsection{Second model: Logistic Regression}

The second model is a multivariate logistic regression model to determine the impact of audit committee variables on the probability of having high discretionary accruals. Discretionary accruals derived from the modified Jones (1995) model is considered high if its absolute value lies within the top $20 \%$ of the sample. The dependent variable $D E M$ is a dichotomous variable that takes the value ' 1 ' if DEM lies above the $80^{\text {th }}$ percentile of the sample and ' 0 ' otherwise.

The binary logit model is expressed as follows:

$\mathrm{DEM}_{\mathrm{i}, \mathrm{t}}=\beta_{0}+\beta_{1} \mathrm{ACSIZE}_{\mathrm{i}, \mathrm{t}+} \beta_{2} \mathrm{ACI}_{\mathrm{i}, \mathrm{t}+} \beta_{3} \mathrm{ACI}_{100} \mathrm{i}_{\mathrm{i}, \mathrm{t}+} \quad \beta_{4} \mathrm{ACMD}_{\mathrm{i}, \mathrm{t}+}$ 


\section{$\beta_{5} \operatorname{ACMDP}_{\mathrm{i}, \mathrm{t}+} \beta_{6} \mathrm{ACDE}_{\mathrm{i}, \mathrm{t}+} \beta_{7} \operatorname{ACMEET}_{\mathrm{i}, \mathrm{t}++} \beta_{8} \mathrm{LEV}_{\mathrm{i}, \mathrm{t}+} \beta_{9} \mathrm{LOGTA}_{\mathrm{i}, \mathrm{t}+} \beta_{10} \operatorname{LOSS}_{\mathrm{i}, \mathrm{t}, \mathrm{t}-1+}$}

$\beta_{11}$ ABCHPAT $_{i, t, t-1+} \beta_{12}$ PB $_{i, t}+\beta_{13}$ BIG $_{i, t}+\varepsilon_{i, t}$

where, ${ }^{D E M_{i, t}}$ is a dummy variable and represents the dependent variable 'earnings management' that is coded ' 1 ' if the absolute value of discretionary accruals lies within the top $20 \%$ of the sample, and ' 0 ' otherwise.

The remaining variables are explained in Table 2 and represent the observations for firm $\mathrm{i}$ in year t.

\subsection{Descriptive Statistics}

Table 3 provides the descriptive statistics for the audit committee variables and control variables. The average size of audit committee is 3.7. There is a wide variation in the committee size, as evidenced by the minimum and maximum values. All companies have complied with the requirements of the Companies Act (2013) as regards the minimum number of members that an audit committee must possess. The largest audit committee has seven members.

Under the new corporate laws in India, majority of the audit committee members need to be independent directors. $98.7 \%$ of the firms complied with this requirement. The mean for ACI100 is 0.338 . This indicates that only $33.8 \%$ of the firms have audit committees comprising entirely of independent directors. Further analysis reveal that a much higher proportion of large-cap firms have 100\% independent audit committees (66.7\%), as compared to mid-cap (30.2\%) and small- cap (25.7\%) firms.

$78.2 \%$ of the firms have audit committees with members holding multiple directorships $(A C M D)$. The mean for the variable $A C M D P$ indicates that $60.7 \%$ of the audit committee members hold multiple directorships. Audit committee expertise is measured by the presence of at least member in the committee with accounting and/or financial expertise. About $62 \%$ of the companies have audit committees with financial experts. Conversely, $38 \%$ of the firms do not have any financial expert on their audit committee. The average number of audit committee meetings for the pooled sample is 4.76 . However, there is a wide variation in the range, as evidenced by the minimum and maximum number of meetings.

Table 3 also shows the descriptive statistics of the six control variables. The average firm in the study has a leverage ratio ( $L E V)$ of $89.2 \%$, which indicates moderately high gearing. The mean for natural logarithm of the total assets of the firm (LOGTA) is 10.19. The minimum (6.72) and maximum (15.45) values of the variable as well as a standard deviation of 1.86 suggest significant variation in the size of the sample firms. The range of values for price to book ratio $(\underline{P B})$ is also considerably high (-.0.840 to 46.97$)$, which is mainly due to the presence of companies with widely varying market capitalization. Only $4.9 \%$ of the companies have reported a loss (LOSS) in two consecutive years, while the average firm has an absolute change in earnings (ABCHPAT) of 0.036 . Moreover, only $25 \%$ of the firms are 
audited by a Big4 (BIG4) auditor. Fees for using the services of a Big4 auditor are considerably on the higher side. This explains why only a quarter of the sample, which includes a higher proportion of small firms, employs a Big4 auditor.

Table 3: Descriptive Statistics

\begin{tabular}{|c|c|c|c|c|}
\hline \multirow[b]{2}{*}{ Variables } & \multicolumn{4}{|c|}{ Pooled Sample $(n=390)$} \\
\hline & Mean & $\mathrm{SD}$ & Min & Max \\
\hline ACSIZE & 3.705 & 0.767 & 3.000 & 7.000 \\
\hline ACI51 & 0.987 & 0.113 & 0.000 & 1.000 \\
\hline ACI100 & 0.338 & 0.474 & 0.000 & 1.000 \\
\hline ACMD & 0.782 & 0.340 & 0.000 & 1.000 \\
\hline ACMDP & 0.607 & 0.338 & 0.000 & 1.000 \\
\hline $\mathrm{ACDE}$ & 0.620 & 0.201 & 0.000 & 1.000 \\
\hline ACMEET & 4.759 & 1.347 & 3.000 & 13.000 \\
\hline LEV & 0.892 & 2.068 & $\begin{array}{l}- \\
6.110\end{array}$ & 29.030 \\
\hline LOGTA & 10.192 & 1.858 & 6.720 & 15.450 \\
\hline LOSS & 0.049 & 0.216 & 0.000 & 1.000 \\
\hline ABCHPAT & 0.036 & 0.068 & 0.000 & 0.593 \\
\hline PB & 3.090 & 4.732 & $\begin{array}{l}- \\
0.840\end{array}$ & 46.970 \\
\hline BIG4 & 0.251 & 0.434 & 0.000 & 1.000 \\
\hline
\end{tabular}

\subsection{Correlation Analysis}

Pearson's correlation analysis is employed to find out the relationship between earnings management and audit committee variables and to test the presence of multicollinearity between audit committee variables. Table 4 presents the results of the univariate analysis. The 


\section{Ml Macrothink}

International Journal of Accounting and Financial Reporting

ISSN 2162-3082

2016, Vol. 6, No. 2

results indicate that all audit committee variables are not significantly related with earnings management (represented by its absolute value $A B E M$ ). There is a significant negative correlation between a 100\% independent audit committee (ACI100) and earnings management. Significant negative correlation is also observed between $A C M D P$ and $A B E M$. This suggests that a higher proportion of audit committee members with multiple directorships may be more effective in constraining earnings management. None of the other audit committee variables show a significant relationship with earnings management. However, the results of the univariate analysis are obtaining without controlling for other confounding factors that might influence the dependent and independent variables. The control variables are included in the multivariate linear and logistic regression models, discussed in the next section.

Of the six control variables, three variables (log of total assets, absolute change in net income and presence of Big4 auditor) show significant correlation with earnings management. Further, Table 4 also indicates significant correlations between some audit committee variables, control variables, and between audit committee and control variables. However there is no problem of multicollinearity among the variables, as all correlations are well below 0.8 (Gujarati, 1995; Abdul Rahman \& Haneem Mohamed Ali, 2006; Lin \& Yang, 2006). Additionally, variance inflation factor (VIF) for each independent variable is calculated and shown in Table 5. VIF for each predictor variable is well below 3. This effectively rules out the problem of multicollinearity among independent and control variables.

Table 4: Correlation (Pearson's) Analysis of Variables

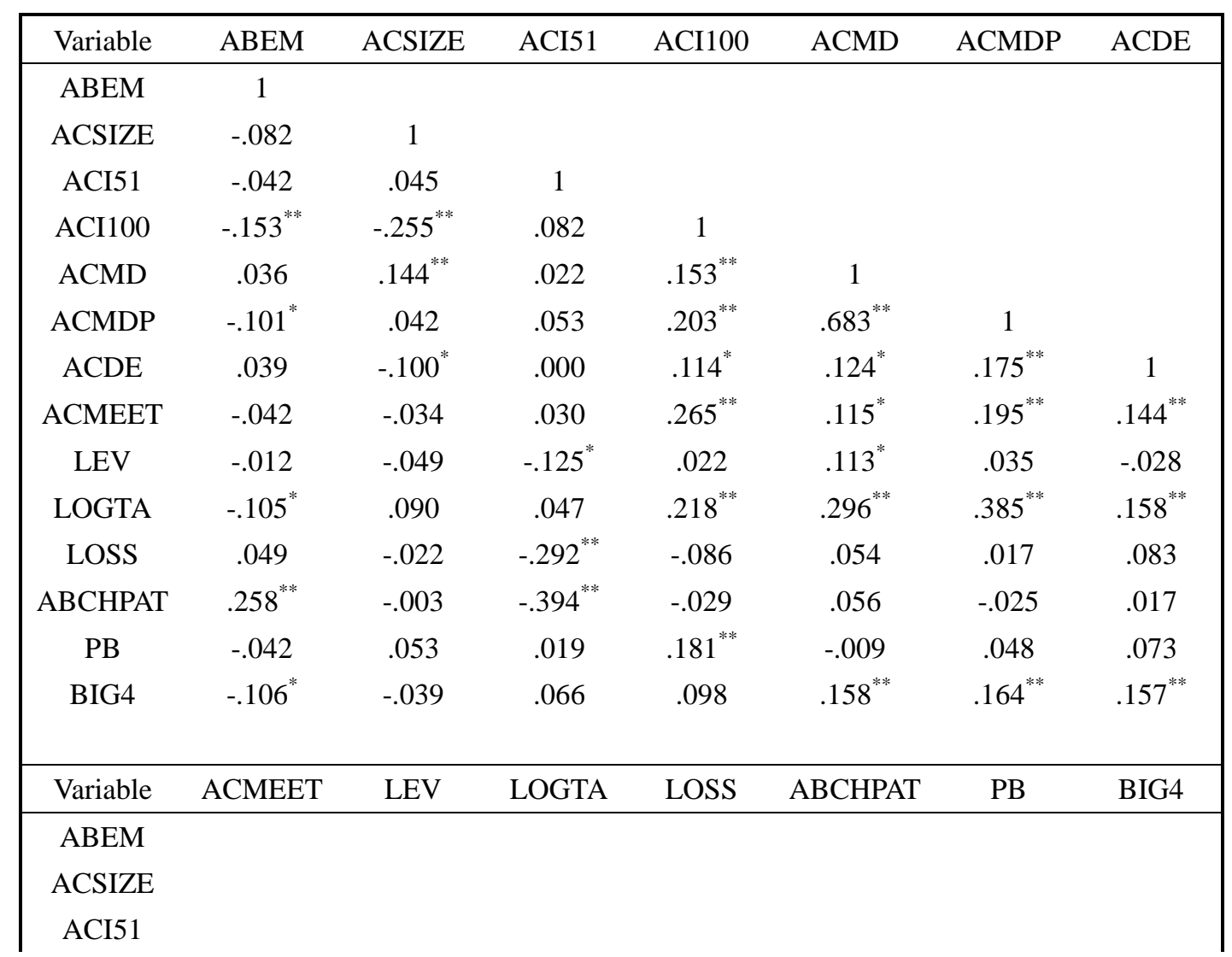




\begin{tabular}{|c|c|c|c|c|c|c|c|}
\hline \multicolumn{8}{|l|}{ ACI100 } \\
\hline \multicolumn{8}{|l|}{ ACMD } \\
\hline \multicolumn{8}{|l|}{ ACMDP } \\
\hline \multicolumn{8}{|l|}{ ACDE } \\
\hline ACMEET & 1 & & & & & & \\
\hline LEV & .049 & 1 & & & & & \\
\hline LOGTA & $.388^{* *}$ & $.251^{* *}$ & 1 & & & & \\
\hline LOSS & .032 & .064 & .061 & 1 & & & \\
\hline ABCHPAT & .009 & -.080 & $-.128^{*}$ & $.108^{*}$ & 1 & & \\
\hline PB & $.140^{* *}$ & -.092 & -.015 & -.089 & .020 & 1 & \\
\hline BIG4 & $.249^{* *}$ & -.035 & $.260^{* *}$ & .006 & -.035 & -.012 & 1 \\
\hline
\end{tabular}

Table 5: Test of Multicollinearity - Variance Inflation Factor

\begin{tabular}{cc}
\hline Variable & Variance Inflation Factor \\
\hline ACSIZE & 1.189 \\
ACI51 & 1.332 \\
ACI100 & 1.315 \\
ACMD & 2.036 \\
ACMDP & 2.124 \\
ACDE & 1.129 \\
ACMEET & 1.311 \\
LEV & 1.166 \\
LOGTA & 1.591 \\
LOSS & 1.149 \\
ABCHPAT & 1.255 \\
PB & 1.101 \\
BIG4 & 1.147 \\
\hline
\end{tabular}

\subsection{Multivariate Regression Analysis}

\subsubsection{Ordinary Least Squares Model}

Table 6 reports the results of the first regression model using the OLS method. The linear regression model is used to test the impact of the predictor variables on the dependent variable, after controlling for the confounding variables. Prior research suggests that earnings management can be influenced by internal and external factors, which have been controlled for in this model (Dechow et al., 1995; Klein, 2002).

The independent variable ACI51 is removed from the analysis as it is found to be constant for almost $99 \%$ of the observations. This suggests that almost all firms' in the sample have an audit committee with majority independent directors. The related F-statistic for the model 


\section{Macrothink}

International Journal of Accounting and Financial Reporting

ISSN 2162-3082

(5.301) is greater than 4 , which indicates that the model is a good fit. The p-value of the Fstatistic is $<0.05$ at $95 \%$ confidence level. This suggests that the model predicts the scores on the dependent variable to a statistically significant degree. $\mathrm{R}^{2}$ value indicates a moderately explanatory power of the model. The $\mathrm{R}^{2}$ for the model is 0.189 , which indicates that about $18.9 \%$ of the variance in discretionary accruals is explained by the independent variables. This implies that discretionary accruals are caused by factors beyond those considered in this model and can be curtailed to a certain degree through audit committee attributes.

Table 6: Linear regression results

\begin{tabular}{|c|c|c|c|c|}
\hline Variable & Predicted Sign & Beta & $t$-statistic & p-value \\
\hline Constant & & .080 & 3.098 & .002 \\
\hline \multicolumn{5}{|c|}{ Independent variables } \\
\hline ACSIZE & $-/+$ & -.010 & -2.089 & .037 \\
\hline ACI100 & - & -.002 & -.224 & .823 \\
\hline ACMD & $-/+$ & .047 & 3.360 & .001 \\
\hline ACMDP & $-/+$ & -.045 & -3.111 & .002 \\
\hline $\mathrm{ACDE}$ & - & .014 & 1.586 & .114 \\
\hline ACMEET & $-/+$ & .000 & .131 & .896 \\
\hline \multicolumn{5}{|l|}{ Control variables } \\
\hline LEV & + & -.001 & -.413 & .680 \\
\hline LOGTA & - & .000 & -.088 & .930 \\
\hline LOSS & $-/+$ & .002 & .138 & .890 \\
\hline ABCHPAT & $-/+$ & .180 & 3.530 & .000 \\
\hline PB & $-/+$ & -.001 & -1.094 & .275 \\
\hline BIG4 & - & -.020 & -2.380 & .018 \\
\hline \multicolumn{5}{|l|}{ Model Summary } \\
\hline R Square & 0.189 & & & \\
\hline Adjusted R Square & 0.145 & & & \\
\hline F-statistic & 5.301 & & & \\
\hline p-value & 0.000 & & & \\
\hline Sample size & 390 & & & \\
\hline
\end{tabular}

\subsubsection{Logistic regression model}

Table 7 shows the output of the logistic regression model, where earnings management is measured by a dichotomous variable DEM. The Nagelkerke $\mathrm{R}^{2}$ for the model is $28.7 \%$, which suggests the model has a reasonable explanatory power. The model's $\chi^{2}$ is significant ( $\mathrm{p}$ $<0.05)$ at $95 \%$ confidence level. The overall model statistics suggest a good fit.

The models together test the various study hypotheses that audit committee characteristics significantly influence the level of earnings management in Indian companies. The results of the hypothesis tests are discussed in the next section. 


\section{Macrothink \\ International Journal of Accounting and Financial Reporting \\ ISSN 2162-3082 \\ 2016, Vol. 6, No. 2}

Table 7: Logistic regression results

\begin{tabular}{|c|c|c|c|c|c|}
\hline & $\begin{array}{l}\text { Predicted } \\
\text { Sign }\end{array}$ & Beta & Wald statistic & $\mathrm{p}$-value & Exp(Beta) \\
\hline Constant & & .159 & .011 & .915 & 1.173 \\
\hline \multirow{2}{*}{\multicolumn{6}{|c|}{$\begin{array}{l}\text { Independent } \\
\text { variables }\end{array}$}} \\
\hline & & & & & \\
\hline ACSIZE & $-/+$ & -.265 & 1.436 & .231 & .767 \\
\hline ACI100 & - & .899 & 1.928 & .108 & 2.458 \\
\hline ACSTOCK & $-/+$ & -.447 & 1.709 & .191 & .640 \\
\hline ACMD & $-/+$ & 3.222 & 18.009 & .000 & 25.086 \\
\hline ACMDP & $-/+$ & -2.438 & 15.170 & .000 & .087 \\
\hline $\mathrm{ACDE}$ & - & .370 & .963 & .327 & 1.448 \\
\hline ACMEET & $-/+$ & -.574 & 7.717 & .005 & .563 \\
\hline ACWB & $-/+$ & .135 & .186 & .666 & 1.144 \\
\hline \multicolumn{6}{|l|}{ Control variables } \\
\hline LEV & + & -.083 & .605 & .437 & .920 \\
\hline LOGTA & - & .045 & .200 & .655 & 1.046 \\
\hline LOSS & $-/+$ & -1.512 & 2.135 & .144 & .220 \\
\hline ABCHPAT & $-/+$ & 7.543 & 10.227 & .001 & 1886.958 \\
\hline $\mathrm{PB}$ & $-/+$ & -.194 & 6.410 & .011 & .823 \\
\hline BIG4 & - & -1.163 & 7.340 & .007 & .312 \\
\hline \multicolumn{6}{|l|}{ Model Summary } \\
\hline-2 Log likelihood & 296.004 & & & & \\
\hline $\begin{array}{l}\text { Cox \& Snell } R \\
\text { Square }\end{array}$ & 0.181 & & & & \\
\hline Nagelkerke R Square & .287 & & & & \\
\hline Chi-square & 73.847 & & & & \\
\hline $\mathrm{p}$-value & 0.000 & & & & \\
\hline
\end{tabular}

\section{Hypothesis Testing}

\subsection{First Hypothesis}

The first hypothesis of the study predicts earnings management to be independent of the size of the audit committee. The linear regression output of the first model (Table 6) shows a reasonably significant and negative impact of the size of audit committee $(A C S I Z E)(\mathrm{p}<0.05)$ on the magnitude of discretionary accruals. The regression results suggest that a large audit committee is more effective at reducing the magnitude of discretionary accruals. A larger committee draws on the expertise of a greater number of members and may be in a better position to discover and question management on dubious accounting practices. The results do not support the first hypothesis and agree with the findings of Huang \& Liu (2005) and Lin \& Yang (2006) that larger audit committees are more effective at monitoring the financial 


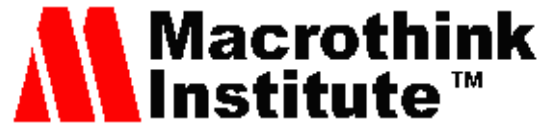

International Journal of Accounting and Financial Reporting ISSN 2162-3082 2016, Vol. 6, No. 2

reporting process. This implies a lesser degree of discretionary accruals and improved earnings quality.

\subsection{Second Hypothesis}

The second hypothesis seeks to examine the impact that independent directors on the audit committee have in restraining earnings fabrication in financial statements. Results of the first model in Table 6 indicate a statistically insignificant relationship between the variable ACI100 and earnings management ( $\mathrm{p}>0.05$ ). This is reinforced by the output of the logistic regression model in Table 7 that shows no significant impact of a $100 \%$ independent audit committee on the level of discretionary accruals ( $p>0.05)$.

The results from both the models do not support the second hypothesis. An audit committee comprising entirely of independent directors has no impact in constraining earnings management. The findings are somewhat similar to Klein (2002) and Kuang (2007) who state that once majority of audit committee directors are independent, the independence of the remaining directors becomes immaterial to have any significant influence on earnings management.

\subsection{Third Hypothesis}

The third hypothesis assumes no significant impact of multiple directorships of audit committee members on earnings management. Two measures of multiple directorships are included in the regression model. Results in Table 6 indicate that percentage of directors with multiple directorships $(A C M D P)$ has a significant negative impact $(\mathrm{p}<0.05)$ on discretionary accruals, whereas the coefficient for majority of audit committee directors with multiple directorships $(A C M D)$ is statistically significant $(\mathrm{p}<0.05)$ and positive.

Table 7 shows the output of the logistic regression model. The Wald statistics of $A C M D$ and $A C M D P$ are the highest, indicating that multiple directorships' of audit committee members have the maximum influence on the level of discretionary accruals. The p-values of the Wald statistic for both variables are significant $(\mathrm{p}<0.05)$. The exponential beta of $A C M D P$ is less than 1, which indicates a negative impact of percentage of directors with multiple directorships on the magnitude of earnings management. The exponential beta of $A C M D$ is greater than 1, and denotes a positive impact of the variable on the level of discretionary accruals.

The overall results from both models indicate that audit committee members with multiple directorships bring in diverse experience and skill sets and are able to restrain earnings management practices. This is in line with the labour market theory and supports the findings of Davidson et al. (1984) and Sharma \& Iseline (2006). However, this favourable impact ceases once majority of the audit committee members' hold multiple directorships. This suggests that once majority of the audit committee members possess multiple directorships, the committee become busy and overcommitted and this reflects in its monitoring function. To this extent, the results agree with Beasley (1996) that increase in directorships can increase the occurrence probability of financial statement fraud. The findings reject the null hypothesis in $\mathrm{H} 3$ of no significant impact of multiple directorships of audit committee 
members on earnings management.

\subsection{Fourth Hypothesis}

The hypothesis seeks to examine if having financial experts on the audit committee improves earnings quality. The regression output on Table 6 indicates that the presence of at least one financial expert on audit committee $(A C D E)$ has no statistically significant impact on earnings management ( $\mathrm{p}>0.05$ ). Table 7 documents a similar result that having an expert director on the audit committee does not produce any significant influence on the level of discretionary accruals. The results do not support hypothesis H4, as well as the findings of Bedard et al. (2004) and Yang \& Krishnan (2005) who infer a significant negative association between audit committee expertise and earnings management. The results of the test are more in agreement with Xie et al. (2003) and Abbott et al. (2004) who show earnings quality to be independent of the financial experience of audit committee directors.

\subsection{Fifth Hypothesis}

The hypothesis assumes no significant impact of audit committee meetings on earnings management. The regression results on Table 6 show no significant impact of audit committee meetings (ACMEET) on earnings management ( $\mathrm{p}>0.05)$. However, when tested in a binary logit model (Table 7), frequency of audit committee meetings produces a significant negative impact on the level of discretionary accruals $(\mathrm{p}<0.05)$. Audit committees that meet more often are likely to be actively involved in monitoring the financial reporting process. The results seem to support the findings of Abbott et al. (2004) that a diligent audit committee, measured by the frequency of its meetings, is significantly associated with lower financial misstatements. A proactive audit committee that meets more frequently during the year has greater opportunities to discuss financial reporting issues and is more likely to spot process anomalies and deviation from standard accounting practices. The results reject the null hypothesis of no significant impact of audit committee meetings on earnings management.

\section{Conclusion}

Prior studies conducted in India explore the association between board characteristics and earnings management. Audit committees are a subset of the board with specific responsibility of overseeing the financial reporting process. This study is evidently the first of its kind in India to explore the impact of audit committees in preserving earnings quality and integrity of financial statements. Though a fair amount of studies in this area exist in the U.S. and other developed and developing economies, the uniqueness of the Indian corporate environment renders the results of these studies inapplicable in the Indian context. Governance measures in the U.S. and U.K. essentially focus on bridging the gap between the management and the dispersed shareholders. In India, presence of a significant number of family controlled businesses calls for a different set of governance measures. Further, law enforcement in India is often the weakest link in ensuring compliance with corporate governance regulations.

The study attempts to examine the influence of audit committees in restraining earnings manipulation. Audit committees constitute one of the most important limbs of corporate 


\section{NI Macrothink}

International Journal of Accounting and Financial Reporting ISSN 2162-3082 2016, Vol. 6, No. 2

governance. The findings of this study show that Indian companies are in compliance of the company laws with respect to the existence and constitution of audit committees. The entire sample of companies considered in this study had constituted an audit committee of the board with a minimum of three directors. Audit committees with a larger number of members experience lower levels of earnings management. Large audit committees benefit from the diverse experience and skills of members and are able to do a more effective job in monitoring the financial reporting process.

Almost all companies have a majority of independent audit committee directors. A wholly independent audit committee has no influence on earnings management. The analysis reveals that multiple directorships of audit committee members have the maximum impact on reducing earnings management. However, once majority of audit committee members become busy, the monitoring function suffers. The study does not find any impact of having financial experts on the audit committee on the quantum of earnings management. However, a higher frequency of audit committee meetings decreases the probability of having high discretionary accruals.

The study contributes to the existing literature by examining how audit committee characteristics impact earnings management in an emerging economy, like India. It throws up useful insights for regulators and company boards to evaluate the efficacy of board audit committees and implement additional governance measures to help preserve the integrity of financial statements.

As with any research, the study has its own limitations. The findings of this study hold good to the extent of accuracy of the disclosed information in company annual reports. Inadequate and inconsistent reporting practices in the smaller firms' preclude the study from considering certain variables, which might yield additional information on earnings management. The modified Jones model is used to estimate earnings management. To validate the model, firms belonging to certain industries are excluded from the sample. Further research in this area by taking a larger sample and alternative measures of earnings quality may throw up insightful results.

\section{References}

Abbott, L. J., Parker, S., \& Peters, G. F. (2002). Audit committee characteristics and financial misstatement: A study of the efficacy of certain blue ribbon committee recommendations. Available at SSRN 319125.

Abbott, L. J., Parker, S., \& Peters, G. F. (2004). Audit committee characteristics and restatements. Auditing: A Journal of Practice \& Theory, 23(1), 69-87.

Abdul Rahman, R., \& Haneem Mohamed Ali, F. (2006). Board, audit committee, culture and earnings management: Malaysian evidence. Managerial Auditing Journal, 21(7), 783-804.

Ajit, D., Malik, S., \& Verma, V. K. (2013). Earnings management in India. SEBI DRG Study. 


\section{Al Macrothink}

International Journal of Accounting and Financial Reporting ISSN 2162-3082 2016, Vol. 6, No. 2

Al-Farah, A. (2001). The effectiveness of audit committees in the Jordanian public shareholding companies: empirical study. Unpublished master's thesis, Jordanian university, Jordan.

Bartov, E., Gul, F. A., \& Tsui, J. S. (2000). Discretionary-accruals models and audit qualifications. Journal of accounting and Economics, 30(3), 421-452.

Bédard, J., Chtourou, S. M., \& Courteau, L. (2004). The effect of audit committee expertise, independence, and activity on aggressive earnings management. Auditing: A Journal of Practice \& Theory, 23(2), 13-35.

Beasley, M. S. (1996). An empirical analysis of the relation between the board of director composition and financial statement fraud. The Accounting Review, 71, 443-465.

Beasley, M. S., \& Salterio, S. E. (2001). The relationship between board characteristics and voluntary improvements in audit committee composition and experience. Contemporary Accounting Research, 18(4), 539-570.

Becker, C. M., Jiambalvo, J., \& Subramanyam, K. R. (1998). The effect of audit on the quality of earnings management. Contemporary Accounting Research, 15, 1-24.

Black, B. S., Jang, H., \& Kim, W. (2006). Does corporate governance predict firms' market values? Evidence from Korea. Journal of Law, Economics, and Organization, 22(2), 366-413.

Blue Ribbon Committee (BRC). (1999). Report and recommendations of the blue ribbon committee on improving the effectiveness of corporate audit committees: New York Stock Exchange and National Association of Securities Dealers. found at www. nyse. com.

Board Committees (2014). The Institute of Company Secrataries of India. Retreived from www.icsi.edu/webmodules/CompaniesAct2013/BOARD\%20COMMITTEES.pdf

Brown, L. D., \& Caylor, M. L. (2005). A temporal analysis of quarterly earnings thresholds: Propensities and valuation consequences. The Accounting Review, 80(2), 423-440.

Bryan, D. M., Liu, C., \& Tiras, S. L. (2004). The influence of independent and effective audit committees on earnings quality. Working Paper, State University of New York, Buffalo.

Claessens, S., \& Fan, J. P. (2002). Corporate governance in Asia: A survey. International Review of finance, 3(2), 71-103.

Companies Act (2013). Ministry of Company Affairs. Retreived from http://www.mca.gov.in/Ministry/pdf/CompaniesAct2013.pdf

Davidson, R., Goodwin-Stewart, J., \& Kent, P. (2005). Internal governance structures and earnings management. Accounting \& Finance, 45(2), 241-267.

Dechow, P. M., Sloan, R. G., \& Sweeney, A. P. (1995). Detecting earnings management. The Accounting review, 70, 193-225.

DeZoort, F. T. (1998). An analysis of experience effects on audit committee members' oversight judgments. Accounting, Organizations and Society,23(1), 1-21. 


\section{I Macrothink}

International Journal of Accounting and Financial Reporting

ISSN 2162-3082 2016, Vol. 6, No. 2

Dooley, P. C. (1969). The interlocking directorate. The American Economic Review, 59(3), 314-323.

Dyck, A., Morse, A., \& Zingales, L. (2010). Who blows the whistle on corporate fraud?. The Journal of Finance, 65(6), 2213-2253.

Emmanuel, U., Ayorinde, B., \& Babajide, O. (2014). Audit Committee Multiple Directorships and Financial Reporting Quality in Nigeria: An Evaluation of the Interconnectedness using Empirical Evidence. Mediterranean Journal of Social Sciences, 5(20), 628.

Felo, A. J., Krishnamurthy, S., \& Solieri, S. A. (2003). Audit committee characteristics and the perceived quality of financial reporting: an empirical analysis. Available at SSRN 401240.

Ferris, S. P., Jagannathan, M., \& Pritchard, A. C. (2003). Too busy to mind the business? Monitoring by directors with multiple board appointments. The Journal of Finance, 58(3), 1087-1112.

Ghosh, A., Marra, A., \& Moon, D. (2010). Corporate boards, audit committees, and earnings management: pre-and post-SOX evidence. Journal of Business Finance \& Accounting, 37(9-10), 1145-1176.

Goncharov, I. (2005). Earnings management and its determinants: Closing gaps in empirical accounting research. Peter Lang.

Goodstein, J., Gautam, K., \& Boeker, W. (1994). The effects of board size and diversity on strategic change. Strategic management journal, 15(3), 241-250.

Gujarati, D.N. (1995). Basic Econometrics. 3rd ed., McGraw-Hill, New York, NY.

Hamdan, A., \& Mushtaha, S. (2011). The Relationship between Audit Committee Characteristics and Type of Auditor's Report: An Empirical Study on the Public Shareholding Industrial Companies Listed at Amman Bourse. The Arabian Journal of Accounting, 14(1), 109-163.

Hamdan, A. M. M., Mushtaha, S. M. S., \& Al-Sartawi, A. A. M. (2013). The audit committee characteristics and earnings quality: Evidence from Jordan.Australasian Accounting Business \& Finance Journal, 7(4), 51.

Huang, H., \& Liu, L. (2005). The Effects of Audit Committee Characteristics on Investors Perception of Financial Reporting. Working Paper: Florida International University

Jensen, M. C. (1993). The modern industrial revolution, exit, and the failure of internal control systems. Journal of Finance, 48(3), 831-880.

Jiraporn, P., Kim, Y. S., \& Davidson, W. N. (2008). Multiple directorships and corporate diversification. Journal of Empirical Finance, 15(3), 418-435.

Klein, A. (2002). Audit committee, board of director characteristics, and earnings management. Journal of accounting and economics, 33(3), 375-400.

Knapp, M. C. (1987). An empirical study of audit committee support for auditors involved in 
technical disputes with client management. The Accounting Review, 578-588.

Kothari, S. P., Leone, A. J., \& Wasley, C. E. (2005). Performance matched discretionary accrual measures. Journal of accounting and economics, 39(1), 163-197.

Krishnan, G. V. (2003). Does Big 6 auditor industry expertise constrain earnings management?. Accounting Horizons, 17, 1 - 16.

Kuang, C. (2007). Audit committee characteristics and earnings management in New Zealand (Doctoral dissertation, Auckland University of Technology).

Lin, J. W., \& Hwang, M. I. (2010). Audit quality, corporate governance, and earnings management: A meta-analysis. International Journal of Auditing, 14(1), 57-77.

Lin, J. W., Li, J. F., \& Yang, J. S. (2006). The effect of audit committee performance on earnings quality. Managerial Auditing Journal, 21(9), 921-933.

Malhotra, N. K. (2008). Marketing research: An applied orientation, 5/e. Pearson Education India.

Mohanty, P. (2003). Institutional investors and corporate governance in India. National Stock Exchange of India Research Initiative Paper, (15).

Menon, K., \& Williams, J. D. (1994). The use of audit committees for monitoring. Journal of Accounting and Public Policy, 13(2), 121-139.

Puri, R., Trehan, R., \& Kakkar, H. (2010). Corporate governance through audit committee: A study of the Indian corporate sector. The IUP Journal of Corporate Governance, 9(1/2), 47.

Qin, B. (2007). The Influence of Audit Committee Financial Expertise on Earnings Quality: US Evidence. ICFAI Journal of Audit Practice, 4(3).

Qaraqish, S. (2009). The Effect of Audit Committee Characteristics on Earnings Quality An Empirical Study on the Industrial Sector Firms Listed at Amman Stock Exchange. Arab Academy for Banking and Financial Sciences.

Rajpal, H. (2012). Independent Directors and Earnings Management - Evidence from India. International Journal of Accounting and Financial Management Research, 2 (4), 9-24.

Sarbanes, P., \& Oxley, M. (2002). Sarbanes-Oxley Act of 2002. Washington, DC: U.S. Congress.

Sarkar, J., Sarkar, S., \& Sen, K. (2008). Board of directors and opportunistic earnings management: Evidence from India. Journal of Accounting, Auditing \& Finance, 23(4), 517551.

Sharma, V. D., \& Iselin, E. R. (2006). Reputation, tenure and compensation of independent audit committee members and financial restatements. Paper presented at the 2006 American Accounting Association Annual Conference.

Shleifer, A., \& Vishny, R. W. (1997). A survey of corporate governance. The Journal of 


\section{Macrothink \\ International Journal of Accounting and Financial Reporting \\ ISSN 2162-3082 2016, Vol. 6, No. 2}

Finance, 52(2), 737-783.

Singh, J. P., Kumar, N., \& Uzma, S. (2010). Satyam fiasco: Corporate governance failure and lessons therefrom. IUP Journal of Corporate Governance, 9(4), 30.

Smith Committee. (2003). Audit Committees Combined Code Guidance. A Report and Proposed Guidance by the FRC. London: Financial Reporting Council.

Teoh, S. H., Welch, I., \& Wong, T. J. (1998). Earnings management and the long-run market performance of initial public offerings. The Journal of Finance, 53(6), 1935-1974.

Vafeas, N. (1999). Board meeting frequency and firm performance. Journal of financial economics, 53(1), 113-142.

Van Der Zahn, J. W. M., \& Tower, G. (2004). Audit committee features and earnings management: Further evidence from Singapore. International Journal of Business Governance and Ethics, 1(2-3), 233-258.

Xie, B., Davidson, W. N., \& DaDalt, P. J. (2003). Earnings management and corporate governance: the role of the board and the audit committee. Journal of corporate finance, 9(3), 295-316.

Yang, J. S., \& Krishnan, J. (2005). Audit committees and quarterly earnings management. International Journal of Auditing, 9(3), 201-219.

\section{Copyright Disclaimer}

Copyright for this article is retained by the author(s), with first publication rights granted to the journal.

This is an open-access article distributed under the terms and conditions of the Creative Commons Attribution license (http://creativecommons.org/licenses/by/3.0/). 